\author{
Review Article
}

\title{
COMPLETE REVIEW OF AYURVEDIC MANAGEMENT OF RAKTAPRADAR W.S.R. TO BRIHATRAYI AND LAGHUTRAYI
}

\section{Ashwini Karache $S^{1 *}$, Seema Mehere $^{2}$}

${ }^{*}$ PG Scholar, ${ }^{2}$ Professor \& Head, Department of Prasuti Tantra and Stree Roga, Y.M.T. Ayurvedic Medical College, Kharghar, Maharashtra, India.

Article info
Article History:
Received: 28-08-202
Revised : 01-09-2021
Accepted: 10-09-202
Published: 16-10-202
KEYWORDS:
Asrigdara,
Raktapradar,
Menorrhagia,
Brihatrayi,
Laghutrayi.

ABSTRACT
Raktapradar in Ayurveda is characterized by excessive or prolonged menstruation with or
without intermenstrual bleeding, which is one of the most common bleeding disorders in
women. Excessive bleeding from uterus either at the time of menses or in intermenstrual
time is considered as Asrigdara or Raktapradar in Ayurveda. Normal menstrual bleeding
including ovulation or more specifically the organized sequence of endocrine signals that
characterizes the ovulatory cycle, menses regularities, predictability \& consistency. It is
most basic concept that control the endometrial cycle, the volume \& the duration of
menstrual flow. Cyclic regular menstrual bleeding which is excessive in amount \& duration
considered as Menorrhagia. Raktapradar can be correlated with menorrhagia. As per
modern science, menorrhagia is defined as cyclic regular bleeding which is excessive in
amount (>80ml) or duration ( $>7$ days) or both. It is considered as one of the commonest
leading gynecological problem. In modern medicine haemostatic, analgesic and hormonal
therapies are advised for Menorrhagia, which includes hormonal therapy,
antiprostaglandins \& antifibrinolytic agents. These have not proven their definitive efficacy
in spite of high costs; their side effects have led to hormonal imbalances hence it is need of
time to have an integrated and comprehensive therapeutic intervention in Ayurveda to
prevent recurrence\& would overcome the modern medicine limitations. Many herbal \&
herbo-mineral preparations, Shodhan \& Shaman Chikits as per Rugnabal are mentioned in
Ayurveda to cure Raktapradar and related symptoms which can be used as per Anubandha
Dosha and Lakshana.

\section{INTRODUCTION}

Detail description of Strirogvyadhies and various changes that occur during all stages of women life such as puberty, reproductive age, menopause, diseases that occur during these stages and most important treatment mentioned in oldest system of health science i.e., Ayurveda. When the amount of bleeding per vagina is so intense that it reflects organ (endometrial layer) deeply ruptured, this is considered as Raktapradar where abnormality in menstrual cycle leads to excessive secretion of Raja i.e., Pradirana.

\begin{tabular}{|l|l|}
\hline \multicolumn{3}{|c|}{ Access this article online } \\
\hline Quick Response Code & https://doi.org/10.47070/ijapr.v9i9.2075 \\
\hline & \begin{tabular}{l} 
Published by Mahadev Publications \\
(Regd.) publication licensed under a \\
\hline
\end{tabular} \\
\hline
\end{tabular}

This whole explanation mentioned under Raktapradar by Acharya Charak. Due to Pradirana of excessive Raja is also termed as Raktapradar.[1] Menarche marks the beginning of an important stage in a young woman physical reproductive maturation and development. Even before the onset of this entirely natural but potentially disturbing function, a young woman's early psychological reactions to menstruation, and probably also her life long view can be influenced by accuracy of her information and degree of empathy with which this knowledge is conveyed to her In the modern science the process of cyclic menstruation is a natural phenomenon.

Regular menstruation results from the balanced relationship between the endometrium and its regulating factors. In present time due to changing life style with food habits, incidence of excessive and irregular menstrual bleeding is increasing day by day because of which women need to take off from the 
work due to excessive bleeding as this excessive bleeding affects not just physical but also social, emotional and psychological well being and quality of life. So it is been correlated with Menorrhagia. It is defined as cyclic bleeding at normal intervals, the bleeding is either excessive in amount $(>80 \mathrm{ml})$ or duration ( $>7$ days) or both.[2]

It is common phenomena among women at the reproductive age. This type of Artav Vikar is distressing and can cause many complications. In this complete review on Raktapradar, as per Ayurveda (Brihatrayi and Laghutrayi) which include Dosha Pratyaneeka Chikitsa, Nidan, Samprapti and Chikitsa of Raktapradar.

AIM: This review aims at evaluating and discussing the various aspects of Raktapradar considering etiology and pathogenesis as per Brihatrayi and Laghutrayi.

OBJECTIVE: Is to elaborate the Ayurveda management of Raktapradar.

\section{MATERIAL AND METHOD}

The review of Ayurveda literatures encompassed from Brihatrayi and Laghutrayi on Raktapradar and from relative e-sources were compiled and brought less than one heading for better assimilation and execution.

\section{CONCEPTUAL STUDY}

According to author Howkins and Bourne Shaw's text book of Gynecology (16 th edition)Menorrhagia denotes cyclic regular bleeding which is excessive in amount or duration. It is generally caused by conditions affecting the uterus or its vascularity rather than any disturbance of function of the hypothalamic - pituitary - ovarian (H-P-O) axis.

Whenever the uterine endometrial surface is enlarged, the bleeding surface is increased, contributing to excessive bleeding. So, in menorrhagia duration ( $>7$ days) and quantity $(>80 \mathrm{ml})$ of the menstrual loss are increased. In normal menstrual bleeding, platelets aggregation forms clots in the open vessels. Prostaglandins $\mathrm{F}_{2 \alpha}\left(\mathrm{PGF}_{2 \alpha}\right)$ causes myometrial contractions and constricts the endometrial vessels, the repair and epithelial regeneration begin on the third and fourth day of period, by the growth of epithelial cells from the open endometrial glands aided by the vascular endothelial, epidermal and fibroblast growth factor.
In excessive bleeding, with regular menstrual cycles the (H-P-O) axis is intact but endometrial changes gets altered. It is observed that in these cases, $\mathrm{PGE}_{2}$ (Prostacyclin) which is local vasodilator is increased as compared to $\mathrm{PGF}_{2 \alpha}$ in the endometrial tissue.

\section{Definition of Raktapradar Mentioned in Ayurveda (Brihatrayi and Laghutrayi):}

1. In the explanation of Raktapradar, Acharya Charak has clearly mentioned that per vaginal bleeding increase in amount in every Ruthu Chakra (menstrual cycle). The amount of bleeding is so intense that it reflects that the organ is deeply ruptured (intensity of rupture of endometrial lining is more).

2. Acharya Madhav Nidan says that Asrigdara or Raktapradar is a disease where Atyartav or excessive amount of Asrik or Rakta per vagina is seen.

3. Asrigdara/ Raktapradar and Raktayoni considered as under same headline by Acharya Vagbhat where he says that when menstrual blood increases more than the normal amount in every Ruthu Chakra or presence of this bleeding when seen in between two Ruthu Chakra (i.e., Inter-menstrual bleeding).

4. Acharya Dalhan mentioned slightly different opinion about Asrigdara where he says that presence of per vaginal bleeding even if it is less in amount but it can be seen as inter-menstrual period and the duration of this intermenstrual bleeding is short.

5. According to Acharya Bhel, in Pradara disease there is a presence of Shonita/bleeding coming out from wrong passage which leads to Shosa.

Hence generalized consideration on the basis of Ayurveda (Brihatrayi and Laghutrayi) includes Asrigdara or Raktapradar as excessive flow and prolonged duration of menses during menstrual cycle or with or without inter-menstrual bleeding.[3]

According to Acharya Sushruta, excessive and prolonged bleeding during menstruation or even in intermenstrual period, different from the features of normal menstrual blood is called "Asrigdara".[4] The quantitative increase in blood it termed as Asrigdara and excessive discharge of blood is termed as Pradara ${ }^{[5]}$. It is mostly associated with body ache, lower abdominal pain and backache. 
Asridgar Nidan [6,7,8,9]

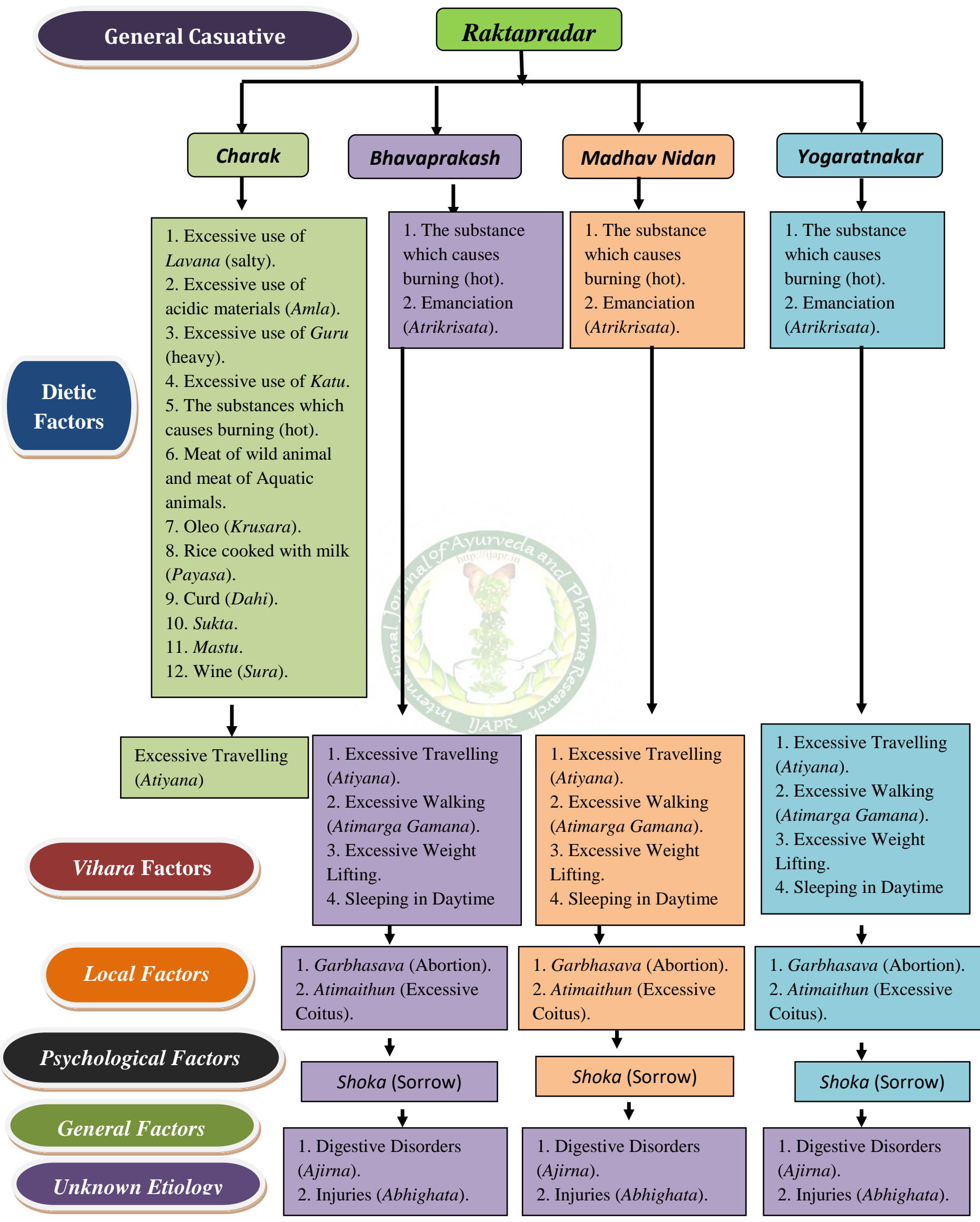




\section{SAMPRAPTI Of ASRIGDARA}

\section{Dosha Dushti}
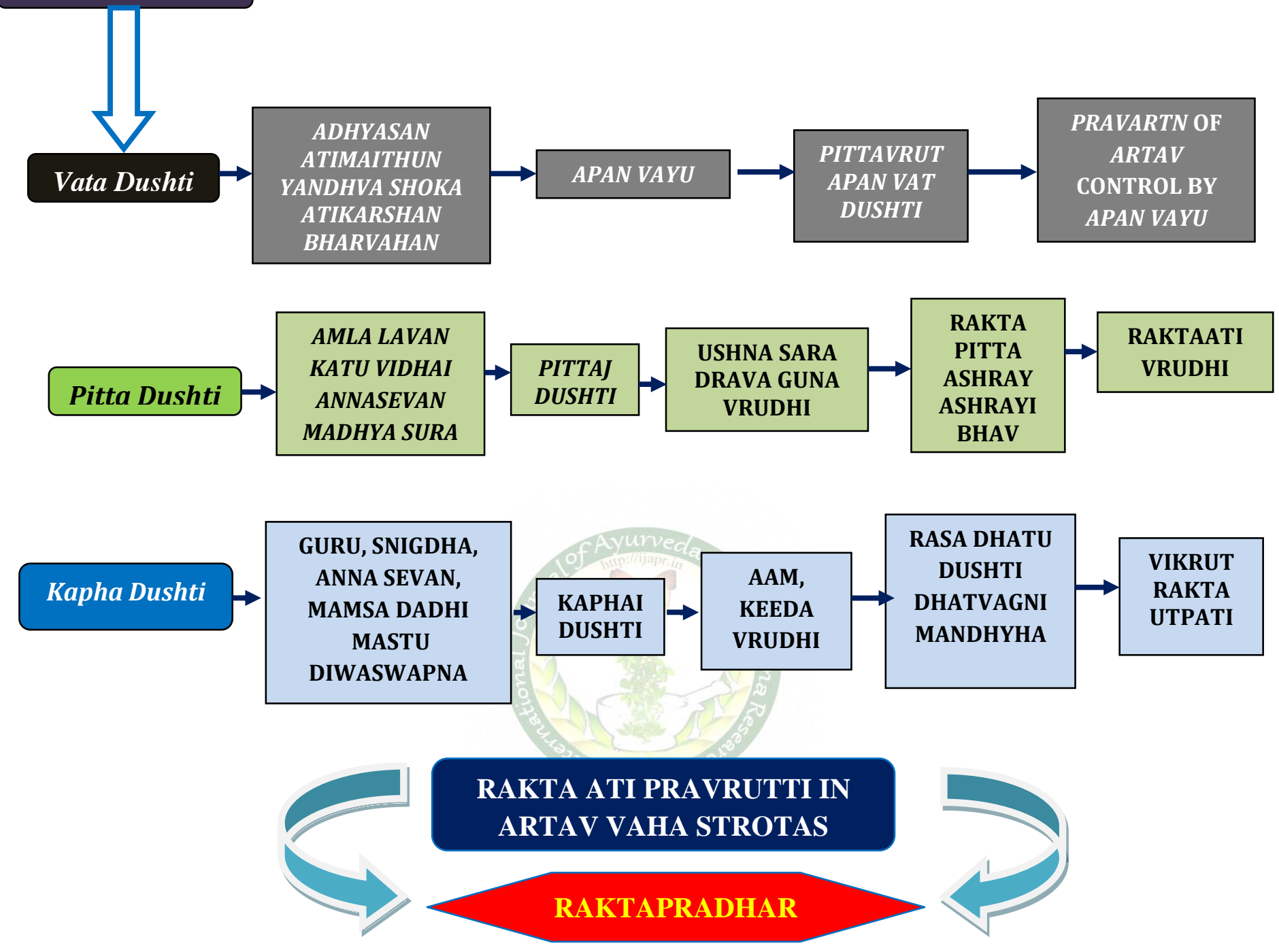

\section{Classification[14,15]}

On basis of Dosha, four common types of Raktapradar by Acharya Charak, Madhav Nidan, Sarangadhara, Bhavaprakash and Yogaratnakar

\section{Vataja Raktapradar/Asrigdara.}

2. Pittaja Raktapradar/Asrigdara.

3. Kaphaja Raktapradar/Asrigdara.

4. Sannipataja Raktapradar/Asrigdara.

For Raktapradar Acharya Vagbhat and Acharya Sushruta did not mention any classification. In the chapter of venesection, by the commentator Acharya Dalhana scripted the exactly similar points i.e., he mentioned special clinical features of Raktapradar depends on physical entities of blood which includes common clinical features as well. Nevertheless, Doshaj Asrigdara/Raktapradar (except Sannipataja Raktapradar), particular treatment and formulations specifically considered by Acharya Charak.
Commentator Indu just like Dalhana has adjusted that the Asrigdara should be divided according to association of Dosha which is to be judged on the basis of features of blood described in venesection. In other word commentator Dalhana classify the Asrigdara into seven groups

1. Vataja

2. Pittaja

3. Kaphaja

4. Vatapittaja

5. Pittakaphaja

6. Vatakaphaja

7. Sannipataja

\section{Nidan}

General etiology or causative factors of Raktapradar are mentioned by Acharya Bhavamisra, 
Acharya Yogaratnakar and Acharya Madhav. Maharishi Sushruta described there is only increased amount of blood loss during intermenstrual period in Raktapradar. Acharya Charak has stressed the importance of only dietic substance in the cause of this disease. Acharya Madhav has explained local contributory factors for the disease.

\section{Sadhya-Asadhyata (Prognosis) [16,17]}

As per all Acharya, prognosis is deprived in the type of - Sannipataja Raktapradar (accepted by all the Acharya).

* Atyartav (Per Vaginum excessive bleeding).

* Angamard (body ache), Daurabalya (generalized weakness), Trishna (thirst), Dah (generalized Burning sensation), Bhram (dizziness), Murcha (unconsciousness), Tandra (drowsiness), Jwara (fever) etc. These are all associated common symptoms. Less amount of blood in the body.

* Raktanyunata (Anemia- Less amount of blood in the body).

\section{Upadrava (Complication) ${ }^{[18]}$}

As per Acharya Sushruta, when the patient is suffering through following symptoms:

Atyartav (Per Vaginum continuous bleeding) Tama (blurring of vision), Pralap (delirium), Raktanyunat (anemia/loss of blood in the body), Angamard (body ache), Daurabalya (generalized weakness), Trishna (thirst), Dah (generalized Burning sensation), Bhram (dizziness), Murcha (unconsciousness), Tandra (drowsiness), Jwara (fever) and other Vatajanya Vikar Akshepakadi i.e., neurological brain disorders. Acharya Madhava, Bhavamishra and Yogaratnakar have similar opinions. According to Acharya Charaka, Raktapradar is one of the etiological factors of Sotha because this is a well known fact that continuous bleeding leads to anaemia and causes oedema.

\section{Chikitsa Siddhanta (Principle of Treatment) [19-23]}

According to Acharya Charak, Raktastambhak chikitsa and Raktastambhak drug should be used in Raktapradar, same prescribed for Raktayoni Chikitsa. Treatment mentioned in gynaecological disorders should also be used in respective Raktapradar. This same principle and same line of treatment has mentioned in Raktatisara (diarrhea with blood) Raktapitta (bleeding diathesis), Raktarsa (bleeding piles) Guhyaroga (diseases of reproductive system) and abortion where Raktastambhak Chikitsa has applied as like in Raktapradar. Commentator Dalhanahas clearly said that Raktapradara should be treated same as like Adhoga Raktapitta. All menstrual disorders should get treated by purgation- this is what prescribed by Acharya Kashyap. According to Chakrapani the Management of Raktapradar runs parallel to the management of Raktapitta treatment.
General overall condition of patient and causative factors decides applicable line of treatment for Raktapradar, because the excessive bleeding per vagina lead to poor general condition and if general condition of patient is very poor, patient cannot tolerate vigorous treatment. So, the aim of treatment is to control the bleeding immediately and remove the cause. While dealing the treatment of Yoniroga, Acharya Charak has specified the treatment according to predominance of Dosha.

- Vataja Yoniroga- Snehan, Swedana and Basti Chikitsa.

- Pittaja Yoniroga- Use of Sheeta material with other treatment of Raktapitta to stop the bleeding.

- Kaphaja Yoniroga- The hot and dry thing should be used.

- Sannipataja Yoniroga- Line of Treatment Decided on the basis of predominance of Dosha and accordingly mixed therapy can also be given.

Acharya Sushruta has mentioned in the treatment of Yoni Roga regarding Snehana and Basti according to Dosha, which is predominant. The main and basic principles for treatment of any Roga for complete and better cure (including Raktapradar) can be divided into following types:-

\section{* Nidan Parivarjanam \\ * Dosha Shodhan \\ * Dosha Shaman \\ - Rakta Sthapana}

Nidan Parivarjanam-This is the pivotal principle which means all types of causative factors- like Aharatmak, Viharatmak or Manasic Hetu/causative factors which leads to development of disease, should get identity first and immediately get removed or eradicated. Without eradication of causative factors no treatment get complete curable result. As neglecting causative factors in treatment of disease increase the chance of recurrence of that disease.

Dosha Shodhan- One of the most important pillars of Ayurveda Chikitsa Paddhati is "Shodhan Chikitsa". It mainly focuses on complete detoxification of body caused by any factors and which leads to imbalance in Dosha, by Shodan Chikitsa this equilibrium get achieved with no relapse. Normally, the Shodhan Chikitsa is considered as use of Panchakarma Chikitsa with Purvarupa. But this therapeutic procedure is contradicted in delicate women and weak person. In Raktapradar there is excessive loss of blood which shows extreme weakness in every woman. As blood contributed in major important components of whole body. Numbers of natural purifying majors are less but there is involvement of Lekhana Karma/curettage has also mentioned. 
> Basti Prayoga: Among the five main Shodhan Chikitsa, Basti contributes majorly and that is the reason why it is denoted as Ardha Chikitsa. There are various types of Basti mentioned in Ayurveda but it's mainly used to achieve balance in Vata Dosha. Basti is nothing but enema of herbal oils (Anuvasan Basti) or decoctions (Niruha Basti) or both. There are many formulations mentioned in Ayurveda following are mainly used in Raktapradar Chikitsa: Rasnadi Asthapan Basti, Chandanadi Niruha basti. [23, 24]

$>$ Vaman Prayog [25,26]- Its one of the important Shodhan Chikitsa which mainly applies for those diseases where cause of Dosha Dushti is Kapha or Predominance of Kapha Dosh is Present. Vaman means emesis therapy where involvement of controlled medical induced vomiting done with the use of "Vaman Yoga/Formulations"

- Madanphala, Saktu, Maddhu Sharkara.

- Madanphala manth/Ikshurasa madhu sharkara.

- Madanphala Yastimadhu Nagarmoth kwatha.

Dosha Shaman- In this process treatment is given according to predominance of Doshas. In other word it is a symptomatic treatment.

Rakta Sthapana- The treatment is given to stop the bleeding. Charak has mentioned a long list of drug for Raktasthapana. For good results, one of the best formulations is considered for treatment of Raktapradar which is Pushyanug Churna similar to this highly reputed formulations which also includes the other drugs which also shows good efficacy and curable outcome for treatment of Raktapradar like Pradarntak Lauha and Prabal Bhasma.

\section{Drugs for External Use}

Vyaghranakhi: (Solanum surattense) grown in the northern direction at uprooted during Uttarphalguni Nakshatra the root tied around waist cures Rakstapradara. [26]

\section{Drugs for Internal Use \\ Kashaya}

1. Pradarhara Kashaya: Kashaya of Khadira, Sita, Bala, Asana, Sariva, Vasa, Japa, Musta, Salmali Twak, Amalaki administered with sugar and honey. [27]

2. Asrgdarahara Kashaya: Musta, Guduchi, Madhuka, Chandana, Sevya, Viswa, Masa, Agnimantha, Kana, Mudga, Kulatha, Chitraka administered early morning with honey. [28].

3. Pathyamalakyadi Kashaya: This decoction mainly used in Rakta Dushti and Pitta Dushti so shows good results in Raktapradar, administered with (Anupan), Madhu and Lodhra Churna. The decoction mainly consists of Pittashamaka and Raktashodak drug like Haritaki, Amalaki, Bibhitaki, Sunthi, Devdaru and Haridra.

\section{Kalka and Churna}

1. Rasanjana and Laksha Churna taken with goat's milk.

2. Kalka of Tanduliyaka Mula with Madhu or Rasanjana with Madhu and rice water. [30]

3. Pushyanug Churna: Patha, Jambu, Amra, Silajita, Rasanjana, Ambashtha, Mocharasa, Samanga, Kesar, Ativisa, Mustaka, Bilwa, Lodhra, Gairika, Katphala, Marich, Sunthi, Mridhwika, Raktachandan, Katvanga, Vatsaka, Ananta, Ghataki, Madhuka, Arjuna administered with honey followed by rice water.[31]

4. Vishveladi Churna: Shunthi, Ela, Kana, Musali, Gokshura, Vanshi, Sita. [32]

\section{Avaleha}

Madhu kadhyaleha, Jirakavaleha,

Khandakushmandavaleha. ${ }^{[33,34]}$

\section{DISCUSSION}

In Raktapradar, every patient presents with the different Dosha Dushti, Lakshana, Samprapti and Doshanubandha. On the basis of considering these important events in Raktapradar, Samprapti Vighatana and Doshanubandha (i.e., Avasthika Chikitsa) decide the exact line of treatment. Asrigdara treated with Raktasthambhak, Raktasthapak, Dipan and Pachan Bruhaniya Balya Chikitsa by utilizing Madhur Tikta Kashaya Rasa Pradhana Dravyas in different types of Samprapti of Asrigdara. Certain herbal or poly herbal Ayurvedic drugs are used to reduce Raktapradar and its complications. Vata Pradhan Raktapradar treated with Madhur Amla Lavana Snigdha Guru Ushna Anuloman Aushadhi i.e., Taila Tila Madhu Lavan Ela Nagar Mamsa rasa etc and Basti chikitsa. When Raktapradar is due to predominance of Pitta Dosha leads to Rakta Dushti so here Pitta Shamaka i.e., drug or formulation with Pitta Kashaya, Madhur, Snigdha, Shita, Dipan, Pachan should be used like Virechan Chikitsa drug in Ghrita formulation. When there is Kapha predominance Raktapradar Aama Pachana is recommended as first step where Pitta Katu Kashaya Rasatmaka, Laghu Ghun and Stamban Kari formulations with Vaman Chikitsa comes under consideration. Triphala Lodhra Nimba shows good results on Kapha predominance Raktapradar. In Pitta predominant Raktapradar where Pitta and Rakta have Ashray Ashrayi Bhava Virechan Chikitsa gives good outcomes.

\section{CONCLUSION}

Raktapradar is one of the common Artav Vikar which affects women health drastically. The clinical condition of Raktapradar is more or less similar to menorrhagia various treatment protocols mentioned in modern science like use of hormonal therapy, antiprostaglandin, anti-fibrinolytic drugs and surgical interventions are mentioned for treatment 
menorrhagia. After the reviewing the aspect of Raktapradar or Asrigdara as per Ayurveda which intends to intervene and proves that the entities discussed in the article are safer, reliable and effective therapies.

\section{REFERENCES}

1. Pt. Rajeswaradatta Shastry and Pt. Yadunandana Upadhyaya. Agnivesha, Charaka, Dridhabala. Charaka Samhita, Chikitsha Sthana, Yoni Vyapad Chikitsha, 30/209, Varanasi; Chaukhambha Bharati Academy; 2011.p. 868.

2. D C Dutta, Text Book of Gynecology, $6^{\text {th }}$ Edition, Jaypee Brothers Medical Publisher (P) Limited, Chapter 14, p185 3.

3. Patil Vasant, M.N.Rajendra, Sushruta Samhita, Volume 2, Chaukhamba Publications, New Delhi, Su, Sa. 2/18,19, p128.

4. Edited by Kaviraja Ambikadutta Shastri. Maharshi Sushruta. Sushruta Samhita, Sharira Sthana, Shukrashonita Shuddhi Sharira, 2/20. Varanasi; Chaukhambha Sanskrit Sansthan; 2009. 15p 5.Nhp.Gov.In.

5. Patil Vasant, M.N.Rajendra, Sushruta Samhita, Volume 3, Chaukhamba Publications, New Delhi Su. S.U 45/44.Page No.378.

6. Vijayarakshita, Srikanthadatta, First Edition 2014, Chaukhambha Surbharti Prakashan, Varanasi, Ma. Ni.61/2 Pg.999.

7. Tripathi Bhrahmanand, Charak Samhita Volume 2, Chaukhamba Surbharti Prakashan, Varanasi Cha. Chi.30/205 Pg.1044.

8. Vaidhya Jayamini Pandey Harit Samhita, Chaukhambha Visvabharti Pra.8/10.

9. Sastri Pandit Kashinath, Chaturvedi Gorakhnath. Charaka Samhita (Chikitsa Sthan). Vol 2. Varanasi; Choukhambha Publication; reprint-2012. p.777.

10. Sashtri Ambika Dutta, Acharya Sushrut, Sushrut Samhita (Uttara Tantra), Ayurveda Tatva Sandipika, Chaukhambha Series. p. 310.

11. Athawale Vaidya Anant Damodar, Acharya Vriddha Vagbhat, Astanga Samgraha (Sarir Sthan) Indu Sanskrit Commentry. p. 262.

12. Sastri Pandit Kashinath, Chaturvedi Gorakhnath. Charaka Samhita (Chikitsa Sthan). Vol 2. Varanasi; Choukhambha Publication; reprint-2012; (C.Chi 30/86).

13. Vidhyasagar Pandit Parshuram Shastri, Sharangdhar Samhita, Edition 2006, Sha.Sa.Pratham Khanda, Chaukhambha Surbharti Prakashan, Varanasi, 7/176 Pg.126.

14. Patil Vasant, M.N. Rajendra, Sushruta Samhita, Volume 1, Chaukhamba Publications, Neh Delhi, Su. Su.14/21, p.178.
15. Tripathi Bhrahmanand, Charak Samhita Volume 1, Chaukhamba Surbharti Prakashan, Varanasi Cha. Chi. 18/ p.367

16. Pandit Shri Bhrhma Sankar Mishra Bhavaprakash Volume 2 Chaukhambha Sanskrit Bhavan p 68/8.

17. Vaidhya Jayamini Pandey Harit Samhita, Chaukhambha Visvabharti Pra.8/10.

18. Sastri Pandit Kashinath, Chaturvedi Gorakhnath. Charaka Samhita (Chikitsa Sthan). Vol 2. Varanasi; Choukhambha Publication; reprint-2012; (C. Chi 30/226).

19. Sastri Pandit Kashinath, Chaturvedi Gorakhnath. Charaka Samhita (Chikitsa Sthan). Vol 2. Varanasi; Choukhambha Publication; reprint- 2012; (C. Chi 30/227).

20. Thakral Kewal Krishna. Sushruta Samhita Chaukhambha Publication; Reprint-2017; (Su.Sa 2/20-21).

21. Thakral Kewal Krishna. Sushruta Samhita. Chaukhambha Publication; Reprint-2017; (S.Utt 45/44, Dalhan).

22. Vidhyasagar Pandit Parshuram Sashtri, Sharandhar Samhita, Chaukhamba Surbhari Prakashan1st Edition 2006 Madhyam Khanda /84-87 p.204.

23. Angadi Ravindra, Bhaisajya Ratnavali, Volume 2 Chaukhambha Surbharati Prakashan 67/59-60 p No.164046. Angadi Ravindra, Bhaisajya Ratnavali, Volume 2 Chaukhambha Surbharati Prakashan 66/59 p.1620.

24. Tripathi Indradeva, Yogaratnakar, Chaukhambha Krushnadas Akadami Varanasi, Strirogadhikara, /53 p.8o7.

25. Vidhyasagar Pandit Parshuram Shastri, Sharangdhar Samhita, Edition 2006, Sha. Sa. Pratham Khanda, Chaukhambha Surbharti Prakashan, Varanasi, 7/176 Pg.126.

26. Patil Vasant, M.N.Rajendra, Sushruta Samhita, Volume 2, Chaukhamba Publications, New Delhi, Su. Su.14/21, p.178.

27. Patil Vasant, M.N.Rajendra, Sushruta Samhita, Volume 1, Chaukhamba Publications, New Delhi, Su.Su.14/21, p.178.

28. Patil Vasant, M.N. Rajendra, Sushruta Samhita, Volume 2, Chaukhamba Publications, Neh Delhi, Su. Sa. 2/19,20, p.128.

29. Tripathi Bhrahmanand, Charak Samhita Volume 1, Chaukhamba Surbharti Prakashan, Varanasi Cha. Chi.18/ p.367.

30. Pandit Shri Bhrhma Sankar Mishra Bhavaprakash Volume 2 Chaukhambha Sanskrit Bhavan 68/8 p.761.

31. Tripathi Bhrahmanand, Charak Samhita Volume 2, Chaukhamba Surbharti Prakashan, Varanasi Cha. Chi.30/227 p.1047. 
32. Ramnias Sharma. Sahastrayoga, Chaukhambha Sanksrut Pratishthan Kashay Prakaran p.7.

33. Ramnias Sharma. Sahastrayoga, Chaukhambha Sanksrut Pratishthan Kashay Prakaran 23 p.10.

34. Ramnias Sharma. Sahastrayoga, Chaukhambha Sanksrut Pratishthan Kashay Prakaran 26 p.12.

35. Tripathi Bhrahmanand, Charak Samhita Volume 2, Chaukhamba Surbharti Prakashan, Varanasi Cha.Chi.30/96 p.1026.

36. Angadi Ravindra, Bhaisajya Ratnavali, Volume 2, Chaukhambha Surbharati Prakashan 66/25-31 p.1616.

37. Ramnias Sharma. Sahastrayoga, Chaukhambha Sanksrut Pratishthan.

38. Pandit Shri Bhrhma Sankar Mishra Bhavprakash Volume 2 Chaukhambha Sanskrit Bhavan 68/17 p.762.

39. Tripathi Indradeva, Yogaratnakar, Chaukhambha Krushnadas Akadami Varanasi, Strirogadhikara, 38/41 p.805.
40. Pandit Shri Bhrhma Sankar Mishra Bhavprakash, Volume 2, Chaukhambha Sanskrit Bhavan 949-57 p.118.

41. Tripathi Indradeva, Yogaratnakar, Chaukhambha Krushnadas Akadami Varanasi, Strirogadhikara, 43 p.806.

42. Tripathi Indradeva, Yogaratnakar, Chaukhambha Krushnadas Akadami, Varanasi, Strirogadhikara, /44-45 p.806.

43. Tripathi Indradeva, Yogaratnakar, Chaukhambha Krushnadas Akadami, Varanasi, Strirogadhikara, /46-51 p.806.

44. Vidhyasagar Pandit Parshuram Sashtri, Sharandhar Samhita, Chaukhambha Surbhari Prakashan1st Edition 2006 Madhyam Khanda /45-50 p.218.

45. Tripathi Indradeva, Yogaratnakar, Chaukhambha Krushnadas Akadami Varanasi, Strirogadhikara, /60 p .8o6.

\section{Cite this article as:}

Ashwini Karache S, Seema Mehere. Complete review of Ayurvedic Management of Raktapradar w.s.r. To Brihatrayi \& Laghutrayi. International Journal of Ayurveda and Pharma Research. 2021;9(9):51-58.

https://doi.org/10.47070/ijapr.v9i9.2075

Source of support: Nil, Conflict of interest: None Declared

\section{*Address for correspondence} Dr. Ashwini Karache S

PG Scholar,

Department of Prasuti Tantra and Stree Roga,

Y.M.T. Ayurvedic Medical College,

Kharghar, Maharashtra, India.

Email:

ashwinikarache@gmail.com

Phone No: 7741052661

Disclaimer: IJAPR is solely owned by Mahadev Publications - dedicated to publish quality research, while every effort has been taken to verify the accuracy of the content published in our Journal. IJAPR cannot accept any responsibility or liability for the articles content which are published. The views expressed in articles by our contributing authors are not necessarily those of IJAPR editor or editorial board members. 